\title{
Old Italian Scrambling: the Low Left Periphery of the Clause
}

\section{Cecilia Poletto}

\section{Introduction1}

In this work I will investigate a phenomenon which has been up to now neglected in the literature on Old Romance languages, namely a set of OV (or better XPV) constructions in Old Italian (OI) which cannot be analyzed as V2 cases, because the verbal form involved is a past participle, not an inflected verb, as shown in (1):

(1) Allora il cavalero, che ' $n$ sì alto mestero avea la mente misa, then the knight, that in so high work had his mind set

(Brunetto Latini, Tesoretto, v. 1975)

I will put forth an analysis in terms of movement of the preverbal XP to a low Focus position located to the left of the low phase vP, similar to (at least one type of) scrambling studied in Germanic languages (see Grewendorf 2005). That such a low left periphery exists has been proposed in the recent literature by a number of authors (notably Jayaseelan 2001, Belletti and Shlonsky 1995, Belletti 2004 for modern Italian and Paul 2002 for Chinese among others). I will adopt this proposal and show that OI displays an interesting parallel between the high left periphery located in the CP layer at the external border of the high CP phase and the low left periphery, so that it is possible to hypothesize that the features of a functional head as Focus are parametrized as phaseindependent properties. Whenever a Focus head is inserted in the syntactic structure (whether in the high or in the low phase) it is bound to be either strong or weak depending on the language, yielding uniformity of behavior across phases. If this view is correct, it predicts that also in the DP phase similar phenomena should be found, and that whenever the property is lost, all the phenomena connected to it in each phase are lost. Thus, in our case V2, scrambling and DP internal movement should be lost all together. ${ }^{2}$ These predictions are borne out. The article is divided as follows: in section 2 I briefly sketch the peculiar type of V2 displayed by OI, in section 3 I present the phenomenon of scrambling. Section 4 contains an explanation of Egerland's (1997) generalization concerning the relation between $\mathrm{OV}$ and past participle agreement patterns and the core proposal that properties of functional heads must be stated phase-independently. Section

1 It is my honor and pleasure to offer this article to Günther Grewendorf, who has been to me a master in research for his rigour and precision and a source of inspiration for his keen and far reaching analyses.

2 As we will see in section 7 V2 is not lost at the same time for all elements. This has already been noticed by Roberts (1993) for Old French: some elements retain the possibility of the V2 construction much longer than others, and this is probably due to their intrinsic possibility of functioning as operators. 
5 shows that the high and the low peft periphery behave alike for the three phenomena already discussed for the CP in section 2. In section 6 I show that the same type of scrambling is found as expected also within the DP phase and in section 7 that Renaissance Italian (RI) lost at the same time V2, scrambling in IP and scrambling in DP as expected. Section 8 concludes the article.

\section{The high left periphery of the clause}

As is well known, OI shows some (but not all) of the typical correlates traditionally associated with the V2 property, namely subject inversion between the auxiliary and the past participle (not to be confused with free subject inversion, which is still possible in modern Italian and occurs after the past participle). ${ }^{3}$

(2) a. quali denari avea Baldovino lasciati loro. which money had Baldovino left them (Doc. fior. 437)

b. ...primieramente avea ella fatta a llui ingiuria, for first had she done to him injury

(Brunetto Latini, Rettorica, 116)

Cases like those in (2) are analysed as movement of the inflected verb to a $C^{0}$ position, as also assumed for Germanic V2.

The licensing of pro drop also shows that the inflected verb is moving higher than in modern Romance, as it is different from the usual system known from modern Romance languages being sensitive to the main versus embedded asymmetry: pro drop is found in main clauses but not in embedded ones, where a subject (possibly weak) pronoun is realized.

(3) E così ne provò _ de' più cari ch'elli avea. and so of-it tested.3sG _ of-the most dear that-he had 'So he tested some of the best friends he had.'

(oFlor.; Testi fiorentini,74)

The standard assumption is that pro can only be licensed when the verb has moved to the CP layer (cf. Benincà (1984) for OI and Roberts (1993) for Old French).

On the other side, OI does not display any linear V2 restriction typical of V2 languages, as V3 cases are frequently attested. ${ }^{4}$

(4) a. Et dall'altra parte Aiaces era uno cavaliere franco and on the other side A. was a knight courageous (Brunetto Latini, Rettorica, p. 94, r. 7)

3 All examples are taken from the OVI data base which contains all Old Italian texts from 1200 to 1350 . I follow here Lorenzo Renzi in defining Old Italian as the Florentine variety written in this period.

4 Cases of V4 and V5 are also attested. This is expected under the hypothesis that there is more than one Topic projection located higher than OpP. 
b. E la reina Artemidora di Alicarnasso, che in adiuto di Serses era venuta, and the queen A. of Alicarnasso, who in help of Serses was come francamente si mescolò nella battaglia courageously herself mingles into the battle (Bono Giamboni, Orosio, p. 92, r. 1)

I will adopt here Benincà's (2005) proposal that the verb moves to the head of an OpP projection defined as FocusP located in the lower portion of the CP layer leaving the higher Topic positions available for other XPs yielding cases of V3. ${ }^{5}$

The structure of the left periphery of OI according to Benincà (2006) is the following:

\section{(5) $\left[\right.$ Force $\mathrm{C}^{0}\left[\right.$ Relwh $\left.\mathrm{C}^{0}\right] /\left\{\right.$ Frame $\left.[\mathrm{ScSett}][\mathrm{HT}] \mathrm{C}^{0}\right\}\left\{_{\text {Toprc }}[\mathrm{LD}][\mathrm{LI}] \mathrm{C}^{0}\right\}\{$ Focus $[$ I Focus $]$ [II Focus]/[Interrogwh $\left.] \mathrm{C}^{0}\right\}\left[\right.$ Fin $\left.\left.^{0}{ }^{0}\right]\right\}$}

The target of verb movement in OI is a projection inside the Focus field, higher positions can only be occupied by Topics (not more than one Focus can be occupied due to minimality reasons).

Another interesting peculiarity of $\mathrm{OI}$ is that it makes extensive use of V1 constructions (which were much more widespread also in Old Germanic languages in contrast to to their modern counterparts)

(6) Avemo ditto che è rettorica

have told what is rhetorics

(Brunetto Latini, Rettorica, p. 5, r. 17)

No matter how these cases are analyzed, whether there is a narrative null operator (corresponding to 'then') as proposed for their Germanic counterpart or V1 is due to movement of the verb to the higher Topic field, it is well know that in these cases clitics are obligatorily found after the inflected verb in enclisis (this is known as a case of the Tobler-Mussafia law): 6

(7) Leggesi di Salamone che...

reads of Salomone that

(Novellino, p.138, r. 1)

Therefore, OI had the following properties connected to the CP left periphery of the clause:

a) V2 constructions in which an XP is preposed to the inflected verb

b) V3 constructions in which a number of Topics could precede the V2 structure

c) V1 with subject inversion

5 A number of other phenomena are connected to V2, as null topics and past participle fronting. They are left aside here because the purpose of this section is to illustrate the similarities between the CP left periphery and the low left periphery.

6 In this work I will use enclisis of the clitic pronoun as an empirical test to provide evidence for the similarity between the high and the low left periphery, I will leave aside the complex matter of deriving enclisis. 
d) When V1 occurs enclisis is the rule

We will see that similar properties also hold for the scrambling phenomenon.

\section{XP V as scrambling to Focus}

Once we factor out the cases of XP V ordering triggered by V2, a number of residual cases are still to be explained, the clearest cases being those with the object located between an auxiliary verb (in $\mathrm{Op}^{0}$ ) and the past participle. Examples like those in (8) cannot be analyzed as movement of the object to the SpecOp position, which is in this case occupied by the subject preceding the auxiliary verb: ${ }^{7}$

(8) a. i nimici avessero già il passo pigliato, the enemies had already the pace taken (Bono Giamboni, Orosio, p. 88, r. 15)

b. ch'egli avea il maleficio commesso that he had the crime committed (Fiore di rett., p. 31, r. 12-13)

c. dice che poi àe molto de ben fatto in guerra et in pace. says that then has a lot of good done in war and in peace (Brunetto Latini, Rettorica, p. 26, r. 22)

d. il quale da che ebbe tutto Egitto vinto,... whom since he had all Egypt won,... (Bono Giamboni, Orosio, p. 83, r. 15)

On the other side, it is not possible to assume that OI was an OV language as unmarked word order is identical to modern Italian and is typical of VO languages:

(9) a. tenea un savio greco in pregione,

kept a wise Greek in prison

(Novellino, p 125, r. 6)

b. fece menare il destriere al campo

let lead the horse to the camp

(Novellino, p.126, r. 13)

c. Molto onoroe la donna nel parto (Novellino, p. 234, r. 7)

A lot honoured the woman in the childbirth

d. Torquato, consolo di Roma, fece per iustizia tagliare la testa al figliuolo Torquato, consul of Rome, had for justice cut the head to the son (Fiori e vita di filosafi, p. 113, r. 2-3 )

Moreover, not only direct objects can be found to the left of the past participle, but any type of internal argument (including passive subjects):

7 Given that cases with a simple verb can always be ambiguous with V2 I will restrict the data to cases of compound tenses. 
(10) a. Ed essendo dell'unico guernimento già ispogliato, and being of the only ornament already stripped (Bono Giamboni, Orosio, p. 411, r. 1)

b. quello che per uso è già dagliantichi servato, what that usually is already from the ancients kept (Bono Giamboni, Vegezio, p. 108, r. 25-26)

c. Non crederei che fosse per voi rotto. (I) not believe that was by you broken (Fiore, p. 442, r. 11)

d. ch'elli è a fine venuto, that he is to end come (Tristano Ricc., p. 397,r. 17)

e. avegna che neuno possa buono advocato essere né perfetto happens that no-one can good advocate be nor perfect (Brunetto Latini, Rettorica, p. 147, r. 1)

f. perciò che quelli cui conviene udire sono già udendo fatigati for that those that have to hear are already listening tired (Brunetto Latini, Rettorica, p. 193, r. 19)

g. se l'avessia mente tenuto, if I it-had in mind kept (Bono Giamboni, Vizi e Virtudi, p. 16, r. 5)

h. Assa'bene, quando sono di te acompagnata, very well, when I am by you accompanied (Bono Giamboni, Vizi e Virtudi, p. 33, r. 2)

i. E quand' ebbi cosí chiaramente a ogni cosa risposto and when (I) had so clearly to everything answered (Bono Giamboni, Vizi e Virtudi, p. 37, r. 24)

j. comandò questo giovane che fossero tutte quelle genti menate (he) ordered this young that were all those people led (Novellino, p. 143. r. 24)

The same is true for (complex) adverbs and verbal modifiers in general, which in their unmarked order usually occur after the past participle: 8

(11) a. e holla già molte volte letta nella Bibbia and have-it already many times read in the bible (Bono Giamboni, Vizi e Virtudi, p. 15, r. 22)

b. a quelli che sono già avanti iti, to those that are already forward gone (Tesoro volg. p. c350, r. 2)

8 The same phenomenon is found with modal verbs and infinitival complements and with causative contructions. 
c. da tutta la gente sarai scarso tenuto of all the people will.(you).be poorly considered (Brunetto Latini, Tesoretto, v. 1561 )

d. Poi lo fece fuori trarre then (he) him made outside take (Novellino, p. 158, rr. 6-7)

e. il cavaliere era molto bene costumato, the knight was so well educated (Novellino, p. 311, r. 3)

f. Quand' ebbero così ordinato When (they) had so ordered (Novellino, p. 349, r. 1)

Given that this is not the unmarked word order of Old Italian, I propose that the ordering found in (8) (10) and (11) is due to a movement operation similar to scrambling targeting a Focus position located in the low IP area. Following Belletti (2004) I take this position to be in the left periphery of the low vP phase. This is clearly a position dedicated to XPs (no clitic or weak elements can occur there as they cannot be focalized), and it hosts virtually any type of constituent, all types of arguments as well as adverbials and verbal modifiers. This lack of "specialization" is a feature typical of left peripheral positions, where any type of XP can be moved.

Suppose further that the "left periphery" of each phase is construed in the same way, namely by merging a "Topic-Focus" field before the highest projection "closing up" the phase (see again Belletti (2004) for modern Italian among others).

Therefore, the examples in (8) (10) and (11) are to be analyzed as cases of movement to a SpecFocus position in front of the past participle but lower than the subject position (SpecAgrS or SpecT in a strict minimalist framework).

\subsection{The relation between scrambling and past participle agreement}

In his (1996) book, Egerland examines only those cases of direct object scrambling and notices that the OV order is diachronically related to the possibility of past participle agreement with postparticipial objects; when postparticipial agreement is lost, OV order is lost as well:

(12) a. quando egli avea già fattị molti miracoli when he had already done+AGR many miracles (Tesoro volg. p. a258, vv. 3-4)

b. E quando il notaio ha letta la proposta dinanzi a'consiglieri, and when the notare has read+AGR the proposal to the counsellors (Tesoro volg. p. d335, v. 17) 
c. c’ha rifiutata la nobile città di Giadres et ha preso li marchi that has refused+AGR the noble city of Giadres and has taken the money (Novellino, p. 133, r. 3)

Moreover, he shows that if the order is VO, past participial agreement is optional (as (12c) shows) while it is obligatory when the order is OV.

This observation is confirmed by modern languages, which still have OV orderings, like Friulian:

(13) a. O ai lis sigaretis dismenteadis.

I have the cigarettes forgotten+AGR

b. O ai dismenteadis lis sigaretis.

c. O ai dismentea:t lis sigaretis.

d. *O ai lis sigaretis dismentea:t.

In modern Friulian only three of the four logical possibilities are attested: the sequence OV without agreement is not possible.

We can reformulate Egerland's observations in the form of two descriptive generalizations as in ( and (14a andb):

(14) a. When past participial agreement is reduced (and finally lost), OV is reduced (and finally lost) as well. ${ }^{9}$

b. Past participle agreement is obligatory with the order $\mathrm{OV}$, but not with the VO order.

Both generalizations can be instrumental to shed light on the account of scrambling in OI.

Generalization (14b) is to be considered a special case of a descriptive generalization proposed by Guasti and Rizzi (2002): focussing on cases of subject agreement they note that movement and morphological richness are connected and propose the following generalization:

(15) If a feature is checked in the overt syntax, then it is expressed in the morphology.

Generalization (15) captures all cases in which a preverbal subject shows stronger agreement than a postverbal subject: when the subject moves to the specifier of AgrS thus checking the AgrS feature in overt syntax, morphology reflects this process, hence the fullest agreement pattern is always selected. This is not always the case for postverbal subjects, where there is not overt checking of the feature in the syntax, thus languages can either have full agreement, a reduced form of it, or no agreement at all. Given Egerland's generalization, confirmed by Friulian data, this is also true for objects: when the object is checking a given feature in overt syntax, this is reflected in the past participle agreement morphology.

$9 \quad$ For data supporting this generalizations see Egerland (1996) and section 6. 
Therefore, OV structures are to be analyzed as cases of overt movement through a position encoding strong features for object agreement ${ }^{10}$ on their way to Focus. The derivation of OV structure is the following: ${ }^{11}$

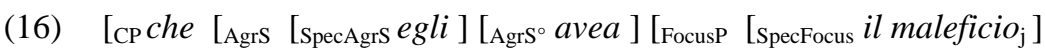

$\left[\right.$ Focus $^{\circ}$ CommessO $\left._{\mathrm{i}}\right]$ [AgrOP $\left[\right.$ SpecAgrO $\left.\left.\left.\left.\left.\mathrm{t}_{\mathrm{j}}\right]\left[\mathrm{AgrO} \mathrm{t}_{\mathrm{i}}\right] \ldots\left[\mathrm{VP}\left[\mathrm{V}^{\circ} \mathrm{t}_{\mathrm{i}}\right]\left[\mathrm{t}_{\mathrm{j}}\right]\right]\right]\right]\right]\right]$

VO structures on the contrary are ambiguous between a movement and a non movement analysis: when there is no agreement, the most natural hypothesis is that no movement has applied to the object DP. Given that movement to Focus is not obligatory, the object DP can stay in its base position. I assume that whenever there is object agreement, there is movement of the object DP to the SpecAgrO position. This means in turn that the past participle must have moved higher than the SpecAgrO position where the DP has moved. I assume that this position is the Focus head.

Hence, the derivation of VO orders is (17a) for non agreeing cases and (17b) for agreeing cases:

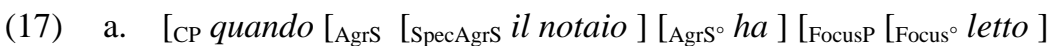

[Agrop [SpecAgro $]\left[\mathrm{AgrO}_{\mathrm{i}}\right] \ldots\left[\mathrm{VP}\left[\mathrm{V}^{\circ} \mathrm{t}_{\mathrm{i}}\right]\right.$ [la proposta $\left.\left.\left.\left.\left.]\right]\right]\right]\right]\right]$

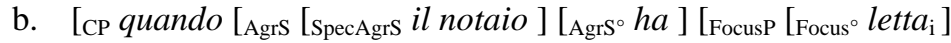

[Agrop [SpecAgro la proposta $\left.a_{\mathrm{j}}\right]$ [Agro $\left.\left.\left.\left.\left.\mathrm{t}_{\mathrm{i}}\right] \ldots\left[\mathrm{VP}\left[\mathrm{v}^{\circ} \mathrm{t}_{\mathrm{i}}\right]\left[\mathrm{t}_{\mathrm{j}}\right]\right]\right]\right]\right]\right]$

Notice that this derives straightforwardly not only generalization (14b) but also (14a): if a strong agreement is always an instance of movement in OI, then loss of movement directly accounts for loss of strong agreement.

Alternatively, in a minimalist framework the agreement pattern with a postparticipial object might be derived via an Agree operation applying freely between the features of the object and those of the past participle. Note that such an hypothesis can also explain Guasti and Rizzi's generalization: given that movement is a complex operation composed of 'match', 'agree' and 'pied pipe', the fact that agreement is obligatory with movement is straightforward in this account.

The main difficulty of this approach is that the Agree operation seems too unconstrained to account for the fact that Italian has lost at the same time OV and post participle agreement (generalization (14a)) and for the fact that the agree operation is now blocked in modern Italian for postsparticipial objects, but not for other types of objects like clitics or passive subjects. In other words, the operation agree is too liberal.

One possible way to constrain the operation is to assume that there is only an indirect link between agreement and syntactic movement and hypothesize that Agree only applies to an in situ object if the language also has a movement operation. Notice however that modern Italian still has agreement with object clitics and passive subjects, so, we have to assume that agreement with a clitic element or agreement with a passive

10 This position could be AgrOP, as originally proposed by Kayne (1991) or another which also has other features, as AspP. I will leave this question open here, although I use the label AgrO for the sake of concreteness.

11 In this work I assume Cinque's (1999) proposal that auxiliaries are functional heads inserted in a functional projection during the derivation and do not have a VP on their own. 
subject would not be sufficient to license agree with postparticipial DPs, only scrambling is. Moreover, the pattern of modern Italian, where agreement is maintained only with those elements that have been moved to the left clearly shows that movement and agreement are directly and not only indirectly linked. Therefore I will discard this analysis here and will continue to assume that strong agreement and movement are directly related (as illustrated in (17)).

Notice that if we are on the right track with the idea that scrambling is movement to Focus there is an interesting parallel between V2 structures and OV structures: in both cases an XP is moved to a SpecFocus and the verb is moved to the head of Focus. If both heads have the same strong property we can hypothesize that the properties of the low Focus position in IP and in the high CP phase remain constant across phases.

It is a fairly standard assumption that the old notion of "parameter" has to be formulated in terms of properties of functional heads. This however often leads to postulating a parameter for a single syntactic construction, while the original notion of parameter has proven extremely powerful in the GB account because it accounts for a number of syntactic constructions on the basis of the same abstract property. Assuming that properties of functional heads remain constant across phases is a new way to account for different phenomena (in our case V2 and scrambling) on the basis of the same abstract feature. I will therefore assume that the strongest version of this proposal, namely that a parameter corresponds to the "activation" of a given $\mathrm{F}^{0}$, whose features must be checked in the computational component wherever it is merged.

Hence, Focus in Old Italian maintains the same property throughout all the phases where it occurs: more specifically it must be filled by a verbal head in all phases, the inflected verb fills the Focus ${ }^{0}$ of the high phase, the past participle fills the Focus ${ }^{0}$ of the low phase.

In the high CP-phase it triggers the subject inversion phenomenon typical of V2 contexts (and the other phenomena seen in section 2). In the vP phase it triggers postparticipial agreement, $\mathrm{O} \mathrm{V}$ and more generally XP V.

This means that the high and the low left periphery should behave alike in all respects, whichleads to a number of expectations concerning the low left periphery on the basis of the constructions illustrated in section 2 for the high left periphery. More specifically, I will examine here three constructions: a) as there are several left dislocated items in the high left periphery, this analysis predicts that more than one scrambled element above the past participle should be possible as well. b) Moreover, as there exists V1 in the high left periphery, this should be the case also in the low left periphery.

c) As seen in section 2, V1 constructions always trigger enclisis in the high phase. Accordingly, the same should hold in the low one.

Two additional predictions are made by the analysis proposed here. The first concerns OI itself: if the strong feature of Focus is phase-independent we should find similar phenomena in the DP as well, given that DP is also a phase.

The second prediction is a diachronic one, namely that if V2 and XP V are effects of the same abstract property, they should be lost together. An apparent problem is raised by the equation between V2 and scrambling: of the two phenomena are always connected we should expect them to cooccur in all languages. This is clearly not the case, as there are languages with scrambling (for instance Korean) but which do not display 
V2. The problem here is that the terms V2 and scrambling have to be qualified in terms of properties of a functional projection. The peculiar type of V2 found in OI is not the "standard" one described for Germanic languages, and as such it probably targets a much lower position in the left periphery. In other words, V2 is a complex phenomenon that always involves the left periphery but not always the same FP. The same is true of scrambling, as different types of scrambling (notably A and A') are known in different languages. Hence, given that V2 and scrambling do most probably not target the same projection in all languages, this analysis does not predict that the two phenomena always together. If both phenomena are complex in the sense that there are some elements are "stronger" in triggering V2 (as for instance wh-items, which still require residual V2 in English, or adverbs like "always" or "never") than others, the same could be true for scrambling, which would also progressively restrict the number of elements moved, just as we observe in the progressive loss of V2.

\section{First prediction: the analogy of the high and the low phase}

As seen in section 2, OI displays frequent V3 constructions, where one (or several) Topic precedes the Focus element. This is, as expected, also found in the low left periphery:

(18) a. ed ha'mi la cosa molte volte ridetta and has the thing many times retold (Bono Giamboni, Trattato, p. 131)

b. E quand' ebbi cosí chiaramente a ogni cosa risposto and when had so clearly to everything answered (Bono Giamboni, Vizi e Virtudi, p. 37, r. 24)

The examples in (18) show that two elements occurs to the left of the past participle. In (18a) they are the direct object la cosa and the adverbial XP molte volte, in (18b) the indirect object a ogni cosa and the adverbial XP così chiaramente. Notice that this type of adverbial XPs usually occur after the past participle, as shown in (19), hence cases like (18) are genuine cases of multiple scrambling of an argument and an adverbial:12

(19) Tullio dice, che 'I fatto è contato chiaramente, Tullio says that the deed is told clearly (Tesoro volg. p. 138, r. 6-7)

12 Notice that in OI chiaramente can only be a low manner adverb, not a high one as in modern Italian (see Poletto 2004 on this). 
The second type of construction frequently found in the high left periphery of the clause is V1: trivially, cases of V1 are also found in the low left periphery, where all objects and lowest adverbs ${ }^{13}$ are located after the past participle

(20) a. ciò che savi avevano detto intorno alla retorica

What that the wise had said about the rhetorics

(Brun. Latini, Rett. P.7 r.19)

b. ...fue isbandito della terra

...was banned from the earth

(Brun. Latini, Rett. P.7 r.9)

c. poi che Tullio ae advisati li mali

since T. has seen the evils

(Brun. Latini, Rett. P.12 r.7)

In other words, cases of V1 in the low phase are "normal" cases of VO.

The third construction found in the high left periphery is the one with V1 and enclisis of a past participle. As for the low phase, it seems difficult to test this possibility as in general it is not possible to leave the clitic inside the low phase, (OI has obligatory clitic climbing to the high phase). ${ }^{14}$

However, absolute participial clauses of non-unaccusative verbs have been analyzed by Belletti (1990) as truncated structures corresponding to AspP in modern Italian. Hence, we can use those cases as a test for our hypothesis:
a. trovò l'arme del re Meliadus, che lli avea fatta sì bella found the weapons of king $M$. that he had done so nice deliberanza, e donatogli: et era suo mortale nemico. disposal, and given-to-him and was his mortal enemy (Novellino p. 268 r. 21)
b. Fatto ha chiamare Licomede re, e dettogli che faccia Made has call Licomede king, and told-him that make chiamare le donne call the women
(Armannino, Fioritap. 546)

As expected, in these cases enclisis is the rule just like in the high phase. We can conclude that the high and the low left periphery really behave alike with respect to the phenomena observed.

13 By lowest adverbs I mean here those adverbs that are usually found after the past participle both in modern Italian and OI when they are not focalized.

14 There are Romance languages such as Piedmontese that leave the clitic on the past participle, but this is not the case in OI. 


\section{Second Prediction: Focus in the DP phase}

The second prediction made by the hypothesis that functional properties are phaseindependent is that within the DP area scrambling phenomena are also possible (and are ungrammatical in modern Italian, which has also lost V2 and IP scrambling).

One interesting fact about $\mathrm{OI}$ is that it is possible to have modified adjectives in prenominal position (contrary to modern Italian):
a. domandò se avesse più care pietre asked if had more valuable stones (Novellino p. 123, 54)
b. qual ti sembra di più ricca valuta? which to you seem of more rich value (Novellino p. 127,28)
c. Democrito fue molto grande filosofo. Democrito was very great philosopher (Fiori e vita di filosafi, p. 106, r. 2)

It becomes clear how examples like (22) are to be interpreted as soon as we notice that adjectives only occurring in postnominal position in modern Italian can occur to the left of the noun: iin OI
(23) a. la quale guardava al figliuolo piccolo del morto fratello, whom looked at the young child of the dead brother (Bono Giamboni, Orosio, p. 148, r. 7)
b. e dagli usati uomini
and from the experienced men
(Bono Giamboni, Vegezio, p. 167, r. )
c. il ben usato cavaliere disidera battaglia the well behaved knight wants battle (Bono Giamboni, Vegezio, p. 70, r. 6)

We can hypothesize that adjectives that are located in a postnominal position in modern Italian can move to the left of the noun due to a DP internal scrambling process, and that modified adjectives do the same. There is empirical evidence that the basic position of the adjective is much lower in the structure than the one where the adjective appears. Consequently we are not dealing here with a language in which the noun raises very little and most adjectives are found to its left (like Germanic languages for instance). Consider the following examples:

(24) a. e di gentile aspetto $\underline{\text { molto }}$ and of kind appearance very (Dante, Vita nuova, cap. 8, par. 1, v. 11)

b. e ciò non è propia natura di cavallo and this not is own nature of horse (Novellino, p. 128, r. 67) 
In (24a), the adjectival modifier molto 'very' has remained to the right of the head noun aspetto 'appearance' and only the bare adjective gentile 'kind' has been extracted out of the complex adjectival phrase and scrambled to the left of the noun. In (24b), the portion of the AdjP left to the right of the noun is its complement PP di cavallo. Cases like (24) clearly show that the prenominal position is not a base generated one, but it is the result of movement of the entire modified AdjP or of part of it.

An even more interesting case is provided by (25).

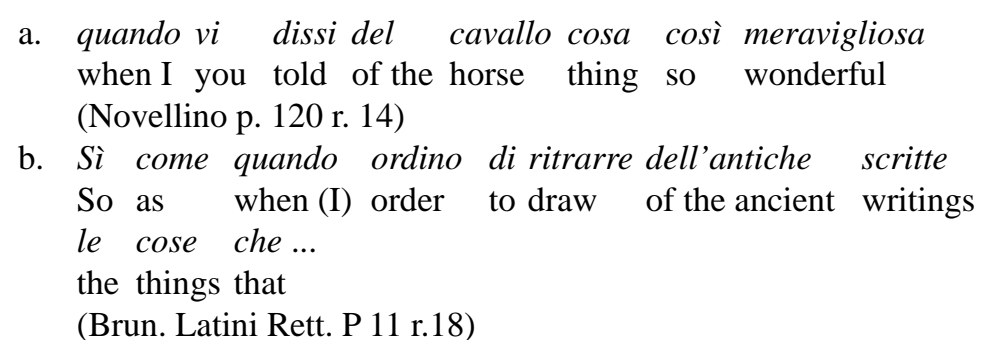

These examples show that it is possible to move even the complement PP of a noun (in (25a) del cavallo, in (25b) dell'antiche cose) to the left. Given that in general object PPs are generated to the right of the noun (OI is not a Complement $\mathrm{N}$ language), (25) clearly shows that OI had a scrambling process in the DP as well as in IP, thus confirming our prediction. ${ }^{15}$

\section{Third prediction: the loss of the medieval system}

As discussed above, the hypothesis that IP-scrambling, V2, and also DP-scrambling are triggered in OI by the same abstract property relating to strong properties of a Focus head located in the left periphery of each phase entails that all these properties are lost

15 A speculation left for future work is the possibility to connect DP scrambling to the fact that OI had very frequent determinerless DPs, in contexts which are completely excluded in modern Italian as in (i). If the parallel between the three phases is complete, the head noun also has to raise to the head of the DP internal Focus position and through this possibly to the higher $\mathrm{D}^{0}$ position. Evidence for $\mathrm{N}$ to $\mathrm{D}$ movement (through Focus) in OI is provided by the frequent cases of determinerless nouns with postnominal possessive adjectives, as illustrated in (ii). See on this Giusti (1992), (1996) and (2004).

(i) a. esser figliolo di pastore to be son of shepherd

b. che uomo vecchio dicesse così grande villania (Novellino, p. 129) that man old said so big rudeness

c. con moltitudine di gente in assedio (Novellino, p. 130) with lot of people in siege

d. donami cavallo $e$ somiere $e$ dispendio ... (Novellino, p. 131) give me horse and helmet and money

e. mandò per maestri sent for masters

(ii) anostra magione (Novellino, p. 128)

Novellino, p. 127)

to our home

(Novellino, p. 128) 
together at the same time and at the same rate. In order to test the prediction, a XVI century text has been examined and screened for all the cases of inversion of the subject, IP scrambling, agreement with a post participial object, and DP scrambling. The text chosen is "Il Principe" by Machiavelli of which the first X chapters and chapters XX-XIII have been considered for an amount of about 120 pages.

The first phenomenon considered is V2: all cases of subject inversion and cases in which new information focus (ungrammatical in modern Italian) is found in first position have been marked.

In the whole sample there are only three cases of subject inversion with an auxiliary verb and eight cases with modals (six with potere 'can' and two with dovere 'must').

(26) a. Spenti adunque questi capi, e ridotti i partigiani loro amici suoi, blown off then this bosses, and reduced their partisan friends, aveva ilduca gittato assai buoni fondamenti alla potenza sua( p.221) had the duke thrown very good foundations to his power

b. Aveva adunque Luigi fatto questi cinque errori (p. 197) had then Luigi made these five mistakes

c. Mentre che durò la memoria, sempre furono i Romani incerti while that lasted the memory always were the Romans unsure di quella possessione (p. 203) of that possession

Cases with modals are the following:

(27) a. E deve soprattutto uno principe vivere con $i$ suoi sudditi and must overall a prince live with the his subjects in modo che ... ( p. 237) so that...

b. E con più facilità se le può un principe guadagnare (p. 205) and with more ease them can a prince gain

As for cases in which new information focus appears in first position, a feature typical of OI syntax which is not found in modern Italian, there exist only four cases of this type (shown in (28)) if we factor out the two adverbs sempre 'always' and mai '(n)ever' which are very frequently placed in first position even in contexts where they do not seem to be contrastively focalized (in which case they are still possible in modern Italian as well):

(28) a. Confido assai che per sua umanità gli debba essere accetta (p. 173) (I) trust a lot that for his humanity to-him must be accepted

b. Più facilmente si tiene una città usa a vivere libera more easily one keeps a city adapted to live free con il mezzo dei suoi cittadini, che in altro modo (p. 204) with the means of its citizens that in other way

c. Come di sopra si disse (p. 213) as above was said 
d. Ordinare che da Firmani fosse ricevuto onoratamente (p. 234) order that from the Firmani was received with honour

(29) a. Sempre si trova dei malcontenti (p. 202) always one finds someone grudging

b. Mai si troverà ingannato da lui (p. 243) never himself-will-find cheated by him

Notice that in non V2 languages like Spanish and Catalan adverbs like corresponding to OI sempre and mai are always found to the left of the inflected verb and are probably located in a dedicated position inside the Focus layer (see Grava (2005)), so they cannot be taken as real indications of a V2 grammar.

Relative clauses deserve particular attention, as instances of V2 embedded under the relative complementizer or wh-item are much more frequent than relative clauses that lack the V2 effect.

$$
\begin{aligned}
& \text { a. Quelli i quali per vie virtuose simili a costoro diventano } \\
& \text { those who along ways winding similar to them become } \\
& \text { principi (p. 210) } \\
& \text { prince } \\
& \text { b. Quelli che di sua qualità gli avevano invidia (p. 211) } \\
& \text { the ones that of his qualities to-him had envy } \\
& \text { c. Quelle armi che vicine lo potevano offendere (p. 223) } \\
& \text { those weapons that close him-could offend }
\end{aligned}
$$

Apparently, the context of relative clauses is special in maintaining V2 longer than other clause types, and this is probably due to the fact that in these cases the CP layer is already activated by the wh item sitting in a higher relative position (see Rizzi (1997) on the position of relative elements). ${ }^{16}$

Therefore, the V2 syntax seems still partially accessible at this stage, though in a restricted way and under special conditions (as in relative clauses). ${ }^{17}$

Egerland (1996) proposed that at this stage two grammars were available, one simulating the OI syntax, which is less frequently used and the new one, in which V2 has already been lost. If we are on the right track, it seems that the V2 grammar still available is subject to specific conditions and very limited in its use.

As for IP scrambling, we have a parallel situation: very few cases of scrambling are found in the sample and they are all resctricted to compound tenses with the auxiliary essere 'be' or copular clauses.

16 One might wonder why this is not the case in interrogative clauses, where a wh-item activated the $\mathrm{CP}$ layer. However, as already shown by Rizzi (1997) interrogative wh-items are located low in the CP structure, in the same Focus field where in OI V2 occurs. Therefore, interrogative wh-items and the focalization of an XP are not compatible.

17 Notice that past participle agreement here originates through movement of the wh-item in the lower phase through a AgrOP and possibly through the low SpecFocus projection. The fact that the activation of the left periphery in the CP phase is mirrored by the activation of the low left periphery of the vP phase in expected in the framework. 
(31) a. Non è, oltre a questo, la provincia spogliata da'tuoi ufficiali (p. 187) not is, beyond this, the province stripped by your officers

b. E benché dai Cartaginesi fusse due volte rotto (p. 232) and although by C. was twice broken

c. Da coloro che saranno in quella malcontenti (p. 190) by those who will-be in that unhappy

d. Non consentono che sia tra gli eccellentissimi uomini (they) not consent that is among the best man celebrato (p. 233) celebrated

e. Che senza l'una e l'altra fu da lui conseguito (p. 233) that without the-one and the-other was by him achieved

Two cases with have have been found, both in a construction with a bare noun:

(32) a. Che esso abbia con loro obbligo (p. 246) that it has with them obligation

b. Altrimenti non ha nelle avversità rimedio (p. 240) otherwise not has in the misfortune remedy

Most relevant examples involve modals (recall that the same observation has been made for subject inversion in the case of V2) or causative constructions:

(33) a. Lo può con grandissima difficoltà perdere (p. 187) it can with greatest difficulty loose

b. Si possono con più difficultà corrompere (p. 202) one can with much difficulty bribe

c. Tanto potette in su tale fondamento edificare ogni edificio (p. 212) so-much could on this foundation build every building

d. Fece da'suoi soldati uccidere tutti i senatori e i più ricchi made by his soldiers kill all the senators and the richest del popolo (p. 232) of the people

e. Non abbiano ancora mai potuto ne'tempi pacifici mantener not have yet ever could in peaceful times keep lo $\quad$ Stato (p. 235) the state

f. Che non fa i fondamenti prima, li potrebbe con una gran virtù that not does the foundations before, them could with great virtue fare dipoi (p. 213) do afterwards

g. Per potere con quelli tenere il papa in freno (p. 224) to can with those keep the pope at bay

Postparticipial agreement is also extremely rare, only five cases are found in the sample:

(34) a. Per aver tenuta più lunga possessione in Italia (p. 93) for have kept ${ }^{+}$AGR more long possession in Italy 
b. Basta avere spenta la linea del principe che enough have turned+AGR off the line of the prince who

li dominava (p. 86)

them dominated

c. Se egli avesse osservate le regole sopradette e tenuti if he had observed+AGR the rules aforementioned and kept+AGR sicuri e difesi tutti quelli suoi amici (p. 195)

safe and protected all those his friends

d. Arebbero sempre tenuti gli altri discosto dalla impresa had always kept+AGR the others away from the enterprise di Lombardia (p. 197) of Lombardy

e. Si vedrà lui aversi fatti gran fondamenti One will-see him have done+AGR grand foundations alla futura potenza (p. 213) to future might

Interestingly, past participle agreement is extremely frequent in relative clauses, that is exactly the same construction in which V2 is still quite consistently found, as discussed above:

(35) a. La quale opera io non ho ornata né ripiena di the which deed I not have adorned+AGR nor filled+AGR of clausole ample (p. 173) big clauses

b. E quelli fondamenti che gli altri hanno fatti avanti che and those foundations that the others have done+AGR before that diventino principi (p. 213) become princes

c. Di quelli cardinali che lui avesse offesi (p. 229) of those cardinals that he had offended+AGR

We can conclude that scrambling and post participial agreement are also extremely restricted and are more frequently found in the same contexts that still trigger V2, namely modals and relative clauses.

DP scrambling, as expected, is also quite restricted but still present:

(36) a. Ed uno de maggiori rimedii e più vivi (p. 187) and one of the main remedies and more powerful

b. Troverà difficultà grande (p. 202) will.find difficulty great

Therefore we can conclude that the Renaissance system exhibits a consistent behaviour of all the phenomena that we attributed to the one and the same abstract property relating to Focus heads. The phenomena are all still present, though apparently only in some constructions, which, at least for V2, scrambling and past participle agreement seem to be the same. 


\section{Conclusion}

In this work I have tried to show that OI is not only a V2 language, but also has scrambling to an IP internal Focus position. Scrambling is both diachronically and synchronically connected to past participle agreement: when scrambling occurs, agreement is obligatory, while only optional when the object occurs in a post participial position; moreover the two phenomena disappear at the same time. I have adopted an analysis of past participial agreement in terms of syntactic movement (and rejected an analysis in terms of the operation agree with in situ objects) of the DP to a SpecAgrO position and further movement of the past participle to Focus.

This analysis of OV orders opens up new perspectives open up for a unitary treatment of functional projections that occur in different phases: if Focus is marked strong in OI independently of the phase where it is merged, V2 and scrambling are two sides of the same coin, one occurring in the high, the other in the low phase. We have seen that the two phenomena have a number of properties in common, for example the possibility of V1 and V3 on a par with V2. The hypothesis of a feature uniformity in all phases further predicts that the same type of reordering phenomena is also found within the DP, which is confirmed by the cases of prenominal adjectives and PPs present in the sample. The last prediction is that all reordering phenomena (i.e. V2, IP and DP scrambling) and past participle agreement are lost at the same time. A close examination of a Renaissance text shows that they all occur mainly in restricted contexts, involving relative clauses and modal and very sporadically in other contexts.

Such a far reaching hypothesis as the one assuming the uniformity of features across phases must clearly be tested in other domains, and in other languages. The first domain of inquiry are other Old Romance languages, to see whether the connection between V2 on the one hand and IP and DP scrambling on the other is confirmed. On the other, it is important to keep in mind that both V2 and scrambling are complex phenomena, they have been analyzed as targeting different projections in different languages (as the well known distinction between asymmetric and symmetric V2 languages or the distinction between A-scrambling and A-scrambling attest) which do not always involve the same head in all languages. This means that we should not compare different types of V2 and different types of (IP and DP) scrambling before we are sure that they really target one and the same head in different languages. This is a very vaste field of inquiry that cannot be tackled in this work, because it is clear that a confirmation of the proposal on the parallel among the CP, vP and DP phases requires a detailed and careful analysis of the phenomena compared as stemming from the same functional head. ${ }^{18}$

\section{References}

Belletti, A. 1990. Generalized Verb Movement. Turin: Rosenberg and Sellier.

18 In a recent work by Ledgeway, he notes that Old Neapolitan has the same features that OI displays, and Old French seems to confirm the connection as well. 
Belletti, A. 2004. Aspects of the low IP area. In: L. Rizzi (ed.), The Structure of CP and IP, 16-51. New York and Oxford: Oxford University Press.

Belletti, A. and U. Shlonsky. 1995. The order of verbal complements: a comparative study. Natural Language and Linguistic Theory 13, 489-526.

Benincà, P. 1984. Un'ipotesi sulla sintassi delle lingue romanze medievali. Quaderni Patavini di Linguistica 4, 3-19. Reprinted in Benincà (1994).

Benincà, P. 1994. La Variazione Sintattica. Bologna: Il Mulino.

Benincà, P. 2001. Syntactic focus and intonational focus in the left periphery. In: G. Cinque and G. Salvi (eds.), Current Studies in Italian Linguistics Offered to Lorenzo Renzi, 39-64. Amsterdam: North-Holland.

Benincà, P. 2006. A detailed map of the left periphery of Medieval Romance. To appear in: R. Zanuttini, H. Campos, E. Herburger, and P. Portner (eds.), Negation, Tense and Clausal Architecture: Cross-linguistics Investigations. Washington. Georgetown University Press.

Cinque, G. 1999. Adverbs and Functional Heads. Oxford: Oxford University Press.

Egerland, V. 1996. The Syntax of Past Participles. Lund: Lund University Press.

Giusti, G. 1992. La sintassi dei sintagmi nominali quantificati. PhD thesis, University of Venice.

Giusti, G. 1996. Is there a FocusP and a TopicP in the noun phrase structure? UVWPL $6.2,105-28$.

Giusti, G. 2004. At the left periphery of the Romanian noun phrase. To appear in: M. Coene (ed.), On the Expression of Time and Space. Bucarest: Clusium.

Grava, R. 2005. Estudio Comparativo entre Italiano Espanol y Catalan sobre la posicion de los denominados adverbios “bajos”. Tesi di Laurea, University of Venice.

Grewendorf, G. 2005. The discourse configurationality of scrambling. In: J. Sabel and M.Saito (eds.), The Free Word Order Phenomenon: Its Syntactic Sources and Diversity, 75-135. Berlin: Mouton de Gruyter [Studies in Generative Grammar 69].

Guasti, M. T. and L. Rizzi. 2002. Agreement and Tense as distinct syntactic positions: evidence from acquisition. In: G. Cinque (ed.), Functional Structure in DP and IP, 167-194. New York and Oxford: Oxford University Press.

Kayne, R. 1991. Romance clitics, verb movement, and PRO. Linguistic Inquiry 22, 647-686.

Jayaseelan, K. 2001. IP-internal Topic and Focus phrases. Studia Linguistica 55.1, 39_ 75.

Ledgeway. A. (to appear). Old Neapolitan word order: Some initial observations. In: A. L. Lepschy and A. Tosi (eds.), Histories of the Italian languages, Oxford: Legenda.

Paul, W. 2002. Sentence internal topics in Mandarin Chinese: the case of object preposing. Language and Linguistics 3.4, 695-714.

Poletto, C. 2004. La struttura della frase in Italiano antico. Ms., University of Padua.

Rizzi L. 1997. The fine structure of the left periphery. In: L. Haegeman (ed.), Elements of Grammar, 281-337. Dordrecht: Kluwer.

Roberts, I. 1993. Verbs and Diachronic Syntax: a Comparative History of English and French. Dordrecht: Kluwer. 